\title{
GENETIC POLYMORPHISM OF THE RORC, BGH, BGHR, LEP, LEPR GENES IN RUSSIAN HORNLESS CATTLE BREED
}

\author{
Ivan Gorlov $^{1,2}$, Galina Sulimova ${ }^{3}$, Aleksey Perchun ${ }^{3}$, Marina Slozhenkina ${ }^{1,2}$ \\ ${ }^{1}$ Volga Region Research Institute of Manufacture and Processing of Meat-And-Milk Production, \\ Russia; ${ }^{2}$ Volgograd State Technical University, Russia; ${ }^{3}$ Institute of General Genetics of the Russian \\ Academy of Sciences, Russia \\ niimmp@mail.ru,galina_sulimova@mail.ru,zooaleks@mail.ru, slozhenkina@mail.ru
}

\begin{abstract}
The purpose of this work is to describe the new beef breed Russian Hornless in terms of the genes associated with the formation of economically valuable traits (RORC, $b G H, b G H R, L E P, L E P R)$ and to evaluate its genetic potential in comparison with the parent Aberdeen-Angus breed. The significant differences were found for the LEPR gene: the $\mathrm{C}$ allele, the $\mathrm{C} / \mathrm{C}\left(t_{d}=3.981, p<0.001\right)$ and $\mathrm{C} / \mathrm{T}(25 \%$ and $1.7 \%$ for Russian Hornless and Aberdeen Angus, respectively) genotypes. Both breeds were registered to have high content of the CC genotype (Leu/Leu) of the $b G H$ gene $(68.3 \%$ and $66.1 \%)$. In the populations of the Russian Hornless and Aberdeen Angus breeds under study, there were revealed 29 and 25 coupled genotypes of 91 ones. There were 6 complex genotypes with a frequency of more than $5 \%$; the $R O R C / b G H / b G H R / L E P / L E P R$ genotypes: $A A / C C / A A / A A / C C(13.3 \%), A A / C C / A G / A A / C C(11.7 \%)$, and $A G / C C / A A / A A / C C(10 \%)$ had the highest frequency. The first two genotypes were present in both breeds and had the same frequency (11.7-15.2\%), the third genotype $(A G / L L / A A / A A / C C)$ occurred 2 times more often in the Aberdeen -Angus breed than in the Russian Hornless breed (20.3\% and $10 \%$, respectively). The high resource potential of the new Russian Hornless cattle breed was confirmed at the molecular genetic level. It should be noted that the developed breed can be used as a beef breed, and the dairy breed as well, as evidenced by the high content of genotypes preferred for obtaining high meat and milk performance.
\end{abstract}

Keywords: animal breeding, marker assisted selection (MAS), single nucleotide polymorphism (SNP).

\section{Introduction}

A new beef breed of Russian Hornless was developed as a result of reproductive crossing of Kalmyk and Aberdeen Angus breeds. The breeding work had the task to produce beef cattle well adapted to the natural conditions of Russia, especially the steppe zone, and to preserve high productivity level and beef quality, typical for the Aberdeen-Angus breed [1-3]. This work was completed in 2007. The cattle of Russian Hornless breed inherited polledness and black colour from the Aberdeen-Anguses and biological features, i.e. a high adaptability to the harsh conditions of the steppe zone of Russia and unpretentiousness to feed from the Kalmyk cattle [4; 5]. This new breed of animals preserved the high beef quality of the Aberdeen-Anguses and by some parameters exceeded them [6-9]. The main distinctive features of the cattle breed developed were the following: its relative tallness, the ability to provide high rate of live weight gain for longer period and to preserve less fat in the body, compared with the animals of the Aberdeen-Angus breed. Nowadays, the population size of newly created Russian Hornless cattle in Russia amounts to about 4000 heads, the breeding stock is mainly bred in the south of the country, in particular in the Volgograd region. LLC "Paris Commune" farm contains 700 heads, the improved breeding stock among them numbers 300 heads; and LLC "Tingutinskoe", by the moment the farm has been renamed into LLC "Volgodon Agro", has 250 heads, the improved breeding stock among them numbers 180 heads. The productive qualities (milk yield, live weight, beef yield and quality) of the Russian Hornless breed were fairly well understood. Today, the blood groups and their antigenic compositions of the breed have also been studied, but the breed has not been characterized with respect to the molecular genetic level using the DNA markers.

This study first presents the single nucleotide polymorphism (SNP) of Russian Hornless genes associated with economically valuable traits: the retinoic acid-related orphan receptor $\mathrm{C}$ gene $(R O R C)$, the growth hormone gene $(b G H)$, the growth hormone receptor gene $(b G H R)$, the leptin gene $(L E P)$, and the leptin receptor gene $(L E P R)$.

The purpose of this work is to describe the new beef breed Russian Hornless in terms of the genes associated with the formation of economically valuable traits: retinoic acid-related orphan receptor $\mathrm{C}$ gene $(R O R C)$, growth hormone gene $(b G H)$, growth hormone receptor gene $(b G H R)$, leptin gene 
$(L E P)$, and leptin receptor gene $(L E P R)$ and to evaluate its genetic potential in comparison with the parent Aberdeen-Angus breed.

\section{Materials and methods}

The material of the study were blood samples of the Russian Hornless breed ( $n=60,50$ cows and 10 calves) from LLC "Tingutinskoe" of Svetloyarsky rayon, the Volgograd region and blood samples of the Aberdeen-Angus breed ( $n=60,50$ cows and 10 calves) from LLC "Don-Agro" of Nekhayevsky rayon, the Volgograd region. These enterprises were chosen because the new breed is grown there, as well as the parent form of it - Aberdeen-Angus breed. The animals selected for the study are purebred with the $100 \%$ bloodiness. The genomic DNA was isolated from the blood samples using a kit of reagents of Diatom ${ }^{\mathrm{TM}}$ Prep200 (IsoGene Laboratory, Russia), according to the manufacturer's instructions. To carry out a polymerase chain reaction (PCR), we applied a kit of reagents of GenePak $^{\mathrm{TM}}$ PCR Core (IsoGene Laboratory, Russia). The primers were synthesized in the Research and Production Company "Litech" (Russia). The nucleotide sequence of the primers, the sizes of the amplification products and the PCR conditions are shown in Table 1.

Table 1

Characteristics of the primers used for PCR amplification, PCR amplification conditions and $P C R$ products size

\begin{tabular}{|c|c|c|c|}
\hline Gene & Sequence of primers & $\begin{array}{r}\text { Temperature, } \\
\text { annealing time }\end{array}$ & $\begin{array}{l}\text { Product } \\
\text { size, bp }\end{array}$ \\
\hline$R O R C$ & $\begin{array}{l}\text { F: 5'- AAGCCCACTGGGCAAGTAGAAGG - 3', } \\
\text { R: 5'- GCAGGGAAGAGCATGTCATTCATTC - 3' }\end{array}$ & $\begin{array}{l}55^{\circ} \mathrm{C} \\
30 \mathrm{sec}\end{array}$ & 249 \\
\hline$b G H$ & $\begin{array}{l}\text { F: 5'- GCTGCTCCTGAGGGCCCTTCG - 3' } \\
\text { R: 5'- GCGGCGGCACTTCATGACCCT - 3' }\end{array}$ & $\begin{array}{l}65^{\circ} \mathrm{C} \\
45 \mathrm{sec} .\end{array}$ & 233 \\
\hline$b G H R$ & $\begin{array}{l}\text { F: 5'- GCTAACTTCATCGTGGACAAC - 3' } \\
\text { R: 5'- CTATGGCATGATTTTGTTCAG - 3, }\end{array}$ & $\begin{array}{l}53^{\circ} \mathrm{C} \\
30 \mathrm{sec} .\end{array}$ & 342 \\
\hline$L E P$ & $\begin{array}{c}\text { F: 5'- GATTCCGCCGCACCTCTC - 3' } \\
\text { R: 5'- CCTGTGCAAGGCTGCACAGCC-3, }\end{array}$ & $\begin{array}{l}63^{\circ} \mathrm{C} \\
30 \mathrm{sec}\end{array}$ & 467 \\
\hline$L E P R$ & $\begin{array}{l}\text { F: 5'- GCAACTACAGATGCTCTACTTTTGT - 3', } \\
\text { R: 5'- CAGGGAAATTTCCCTCAAGTTTCAA - 3' }\end{array}$ & $\begin{array}{l}56^{\circ} \mathrm{C}, \\
30 \mathrm{sec} .\end{array}$ & 400 \\
\hline
\end{tabular}

The resulting amplification products of the RORC, $b G H, b G H R, L E P$, and $L E P R$ genes were treated with restriction endonucleases $A d e \mathrm{I}, A l u \mathrm{I}, A l u \mathrm{I}, B s u 15 \mathrm{I}$, and TaqI, respectively, under the conditions specified by the manufacturer (MBI Fermentas, Germany). The reaction products were separated by electrophoresis in the $2 \%$ agarose gel ("Agarose. Biotechnology Grade", LLC Amresco, USA) in the presence of ethidium bromide (final concentration $0.5 \mathrm{mkg} \cdot \mathrm{ml}^{-1}$ ). As a molecular weight marker we used M50 marker (IsoGene Laboratory, Russia). The electrophoresis results were recorded in the ultraviolet by the gel documentation system "UVT-1" (Biocom Company, Russia).

In this work we used computer databases submitted on the server of the National Center for Biotechnology Information (http://www.ncbi.nlm.nih.gov/).

The presence and the frequency of alleles and genotypes were established according to the results of the molecular genetic analysis. The allelic and genotypic frequencies, the heterozygosity observed (Ho) and expected (He), and the Hardy-Weinberg equilibrium test were calculated using PopGene 3.1 software. The frequency of genotypes was determined by the formula (1).

$$
p=\frac{n}{N},
$$

where $p$-frequency of the genotype determination;

$n$ - number of individuals with a specific genotype;

$N$ - number of individuals.

The frequency of certain alleles was determined by the formulas (2) and (3).

$$
P A=\frac{2 n A A+n A B}{2 N},
$$




$$
q B=\frac{2 n B B+n A B}{2 N},
$$

where $P A-$ frequency of allele A;

$q B$ - frequency of allele $\mathrm{B}$;

$N-$ total number of alleles.

The expected results of the genotype frequencies in the studied population were calculated by the Hardy-Weinberg law.

The data on different variables, obtained from the experiment, were statistically analyzed by the Statistica 10 package (StatSoft Inc., USA). The significance of differences between the indices was determined using the criteria of nonparametric statistics for the linked populations (differences with $p<0.05$ were considered significant: ${ }^{\mathrm{a}} p<0.001 ;{ }^{\mathrm{b}} p<0.01 ;{ }^{\mathrm{c}} p<0.05$; ns $=$ not significant at $p>0.05$ ). Students' $t$-test was applied for the statistical analysis.

\section{Results and discussion}

The allele and genotype frequencies of the RORC, $b G H, b G H R, L E P$, and $L E P R$ genes in Russian Hornless and Aberdeen Angus cattle breeds are shown in Table 2 and 3.

Table 2

Distribution of RORC, $b G H, b G H R, L E P$, and $L E P R$ alleles and genotypes (Russian Hornless)

\begin{tabular}{|c|c|c|c|c|c|c|}
\hline Genotype & $\boldsymbol{n}$ & $\begin{array}{c}\text { Frequency of } \\
\text { genotypes } \pm S p\end{array}$ & Allele & $\begin{array}{c}\text { Frequency of } \\
\text { alleles } \pm S p\end{array}$ & $\boldsymbol{H}_{\text {exp }}$ & $\chi^{2}$ \\
\hline \multicolumn{7}{|c|}{ Retinoic acid-related orphan receptor C gene $R O R C-S N P$ : g. 3984, A>G* } \\
\hline$A / A$ & 37 & $0.616 \pm 0.063$ & \multirow{3}{*}{$\begin{array}{l}A \\
G\end{array}$} & \multirow{3}{*}{$\begin{array}{l}0.775 \pm 0.038 \\
0.225 \pm 0.038\end{array}$} & \multirow{3}{*}{0.349} & \multirow{3}{*}{0.838} \\
\hline$A / G\left(\mathrm{H}_{\mathrm{obs}}\right)$ & 19 & $0.317 \pm 0.060$ & & & & \\
\hline$G / G$ & 4 & $0.067 \pm 0.032$ & & & & \\
\hline \multicolumn{7}{|c|}{ Growth hormone gene $(b G H)-S N P:$ g.49250310, C>G*, L127V $\left.(\mathrm{Leu}>\mathrm{Val})^{* *}, \mathrm{rs} 41923484\right)$} \\
\hline & 41 & $0.683 \pm 0.060$ & \multirow{3}{*}{$\begin{array}{l}L \\
V\end{array}$} & \multirow{3}{*}{$\begin{array}{l}0.808 \pm 0.036 \\
0.192 \pm 0.036\end{array}$} & \multirow{3}{*}{0.310} & \multirow{3}{*}{3.732} \\
\hline$C G\left(\mathrm{H}_{\mathrm{obs}}\right)$ & 15 & $0.250 \pm 0.056$ & & & & \\
\hline$G G$ & 4 & $0.067 \pm 0.032$ & & & & \\
\hline \multicolumn{7}{|c|}{ Growth hormone receptor gene $(b G H R)-S N P: \mathrm{A}>\mathrm{G}^{*}, \mathrm{~S} 257 \mathrm{G}(\mathrm{Ser}>\mathrm{Gly}) * *, \mathrm{AF} 140284 * * *$} \\
\hline$A / A$ & 34 & $0.566 \pm 0.064$ & \multirow{3}{*}{$\begin{array}{l}A \\
G\end{array}$} & \multirow{3}{*}{$\begin{array}{l}0.750 \pm 0.040 \\
0.250 \pm 0.040\end{array}$} & \multirow{3}{*}{0.375} & \multirow{3}{*}{0.045} \\
\hline$A / G\left(\mathrm{H}_{\mathrm{obs}}\right)$ & 22 & $0.367 \pm 0.062$ & & & & \\
\hline$G / G$ & 4 & $0.067 \pm 0.032$ & & & & \\
\hline \multicolumn{7}{|c|}{ Leptin gene (LEP), SNP: A > T*, Y7F (Tyr>Phe)**, rs29004487 } \\
\hline$A / A$ & 52 & $0.867 \pm 0.044$ & & & & \\
\hline$A / T\left(\mathrm{H}_{\mathrm{obs}}\right)$ & 8 & $0.133 \pm 0.044$ & $\begin{array}{l}A \\
T\end{array}$ & $\begin{array}{l}0.933 \pm 0.023 \\
0.067+0.023\end{array}$ & 0.125 & 0.453 \\
\hline$T / T$ & 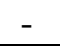 & - & & & & \\
\hline \multicolumn{7}{|c|}{ Leptin receptor gene $(L E P R), \mathrm{SNP}: \mathrm{C}>\mathrm{T}^{*}, \mathrm{~T} 945 \mathrm{M}(\mathrm{Thr}>\mathrm{Met})^{* *}, \mathrm{AJ} 589801 * * *$} \\
\hline $\mathrm{C} / \mathrm{C}$ & 45 & $0.750 \pm 0.056$ & $C$ & $0.875 \pm 0.030$ & \multirow[b]{2}{*}{0.219} & \multirow{2}{*}{1.972} \\
\hline $\mathrm{C} / \mathrm{T}\left(\mathrm{H}_{\mathrm{obs}}\right)$ & 15 & $0.250 \pm 0.056$ & $T$ & $0.125 \pm 0.030$ & & \\
\hline
\end{tabular}

Note: $S p$ is the error of the allele and genotype frequencies; $H_{\text {obs }}$ is the observed heterozygosity; $H_{\text {exp }}$ is the expected heterozygosity; $\chi^{2}$ is the compliance criteria; $g$, is the nucleotide position in the genomic sequence; rs (reference SNP) is the SNP number in the dbSNP database; * is the nucleotide replacement; ** is the amino acid replacement with the location indication in the protein product; *** is the registration number in the GenBank database

Note that the table shows the data obtained for the population of Aberdeen-Angus bred in the Volgograd region and used as the parent form when developing the Russian Hornless breed. Of interest was not only to characterize the Russian Hornless breed in terms of the genes associated with the economically valuable traits, but also to find out how it differs from the parent breed for the allele and genotype frequencies of the genes studied. 
Table 3

Distribution of $R O R C, b G H, b G H R, L E P$, and $L E P R$ alleles and genotypes (Aberdeen Angus)

\begin{tabular}{|c|c|c|c|c|c|c|}
\hline Genotype & $n$ & $\begin{array}{c}\text { Frequency of } \\
\text { genotypes } \pm S p\end{array}$ & Allele & $\begin{array}{c}\text { Frequency of } \\
\text { alleles } \pm S p\end{array}$ & $\boldsymbol{H}_{\text {exp }}$ & $\chi^{2}$ \\
\hline \multicolumn{7}{|c|}{ Retinoic acid-related orphan receptor C gene $R O R C-S N P:$ g.3984, A>G* } \\
\hline $\begin{array}{c}A / A \\
A / G\left(\mathrm{H}_{\mathrm{obs}}\right) \\
G / G\end{array}$ & $\begin{array}{c}28 \\
27 \\
4\end{array}$ & $\begin{array}{l}0.474 \pm 0.065 \\
0.458 \pm 0.065 \\
0.068 \pm 0.033\end{array}$ & $\begin{array}{l}A \\
G\end{array}$ & $\begin{array}{l}0.703 \pm 0.042 \\
0.297 \pm 0.042\end{array}$ & 0.418 & 0.918 \\
\hline \multicolumn{7}{|c|}{ Growth hormone gene $(b G H)-S N P:$ g.49250310, C>G*, L127V (Leu>Val)**, rs41923484) } \\
\hline $\begin{array}{c}C C \\
C G\left(\mathrm{H}_{\text {obs }}\right) \\
G G\end{array}$ & $\begin{array}{c}39 \\
18 \\
2 \\
\end{array}$ & $\begin{array}{c}0.661 \pm 0.062 \\
0.305 \pm 0.060 \\
0.034\end{array}$ & $\begin{array}{l}L \\
V\end{array}$ & $\begin{array}{l}0.814 \pm 0.036 \\
0.186 \pm 0.036\end{array}$ & 0.303 & 0.002 \\
\hline \multicolumn{7}{|c|}{ Growth hormone receptor gene $(b G H R)-S N P: \mathrm{A}>\mathrm{G}^{*}, \mathrm{~S} 257 \mathrm{G}$ (Ser>Gly)**, AF140284*** } \\
\hline $\begin{array}{c}A / A \\
A / G\left(\mathrm{H}_{\mathrm{obs}}\right) \\
G / G\end{array}$ & $\begin{array}{c}36 \\
18 \\
5\end{array}$ & $\begin{array}{l}0.610 \pm 0.063 \\
0.305 \pm 0.060 \\
0.085 \pm 0.036\end{array}$ & $\begin{array}{l}A \\
G\end{array}$ & $\begin{array}{l}0.763 \pm 0.039 \\
0.237 \pm 0.039\end{array}$ & 0.362 & 2.534 \\
\hline \multicolumn{7}{|c|}{ Leptin gene $(L E P), S N P: \mathrm{A}>\mathrm{T}^{*}, \mathrm{Y} 7 \mathrm{~F}(\mathrm{Tyr}>\mathrm{Phe})^{* *}, \mathrm{rs} 29004487$} \\
\hline $\begin{array}{c}A / A \\
A / T\left(\mathrm{H}_{\mathrm{obs}}\right) \\
T / T\end{array}$ & $\begin{array}{c}47 \\
11 \\
1\end{array}$ & $\begin{array}{c}0.797 \pm 0.052 \\
0.186 \pm 0.051 \\
0.017\end{array}$ & $\begin{array}{l}A \\
T\end{array}$ & $\begin{array}{l}0.890 \pm 0.029 \\
0.110 \pm 0.029\end{array}$ & 0.196 & 0.204 \\
\hline \multicolumn{7}{|c|}{ Leptin receptor gene $(L E P R), \mathrm{SNP}: \mathrm{C}>\mathrm{T}^{*}, \mathrm{~T} 945 \mathrm{M}(\mathrm{Thr}>\mathrm{Met})^{* *}, \mathrm{AJ} 589801^{* * *}$} \\
\hline $\begin{array}{c}\mathrm{C} / \mathrm{C} \\
\mathrm{C} / \mathrm{T}\left(\mathrm{H}_{\mathrm{obs}}\right)\end{array}$ & $\begin{array}{c}58 \\
1\end{array}$ & $\begin{array}{c}0.983 \pm 0.017 \\
0.017\end{array}$ & $\begin{array}{l}C \\
T\end{array}$ & $\begin{array}{c}0.992 \pm 0.008 \\
0.008\end{array}$ & 0.016 & 0.006 \\
\hline
\end{tabular}

Notes are the same as in Table 2

There were no significant differences in the observed and expected heterozygosity in both breeds in all genes studied. The RORC gene can show the accumulation of the homozygous $A / A$ genotype in the Russian Hornless breed, its frequency in Russian Hornless exceeds the frequency of this genotype 1.3 times. By reference to the $b G H$ and $b G H R$ genes, the frequencies of the alleles and genotypes did not differ. The homozygous $T / T$ genotype of the $L E P$ gene was not found in Russian Hornless cattle, but in the Aberdeen-Angus selection there was only one animal identified. Significant differences in the frequencies of alleles and genotypes were registered only in terms of the $L E P R$ gene: the $C$ allele frequency $\left(t_{d}=3.768, p<0.001\right)$ and the $C / C$ genotype $\left(t_{d}=3.981, p<0.001\right)$.

The data obtained show that both breeds significantly differ only for the T945M polymorphism in the leptin receptor gene. The tendency of accumulation of the homozygous $A / A$ genotype of the RORC gene was also observed.

We have also described coupled genotypes of all five genes investigated and determined their frequencies. In the populations of Russian hornless and Aberdeen Angus breeds under study, we revealed 29 and 25 coupled genotypes of 91 ones possible in theory. We described 6 coupled genotypes with a frequency of more than $5 \%$ in the Russian Hornless breed and 5 in the Aberdeen Angus breed (Table 4). Three most common coupled genotypes were the same in both breeds. The frequencies of the $A A / C C / A A / A A / C C$ and $A A / C C / A G / A A / C C$ (RORC/bGH/bGHR/LEP/LEPR) genotypes were approximately the same. The third genotype (AG/CC/AA/AA/CC) in the AberdeenAngus breed occurred 2 times more often than in the Russian breed. The rarer coupled genotypes (with a frequency of 0.50 to 0.83 ) were different in the breeds investigated.

The study has found that Russian Hornless and Aberdeen Angus breeds did not differ with respect to the frequency distribution of alleles and genotypes of the genes associated with productivity (RORC, $b G H, b G H R, L E P$, and $L E P R$ ). Significant differences were registered only in frequencies of the $C$ allele $\left(t_{d}=3.768, p<0.001\right)$ and the $C C$ genotype $\left(t_{d}=3.981, p<0.001\right)$ of the LEPR gene. Distribution of the allele frequencies of the genes in the study samples of the Russian Hornless breed was uneven: the allele frequencies for the RORC, $b G H$ and $b G H R$ genes were different 3-4 times, and for the $L E P$ and LEPR genes 14 and 7 times, respectively. Similar pattern was observed in the 
Aberdeen-Angus subset [10]: the allele frequencies of the genes investigated differed 2-12 times. The frequencies of the predominant genotypes and their economic value are presented in Table 5.

Spectrum and rates of predominate coupled genotypes

\begin{tabular}{|c|c|c|c|c|}
\hline \multirow[b]{2}{*}{$\begin{array}{l}\text { Predominate complex genotypes: } \\
R O R C / b G H / b G H R / L E P / L E P R\end{array}$} & \multicolumn{4}{|c|}{ Russian Hornless } \\
\hline & $\begin{array}{l}\text { Frequency of } \\
\text { predominate } \\
\text { genotypes }(p)\end{array}$ & $\begin{array}{l}\text { Number of } \\
\text { identified } \\
\text { genotypes }\end{array}$ & $\begin{array}{c}\text { Number of } \\
\text { genotypes, } \\
p \leq 5 \%\end{array}$ & $\begin{array}{c}\text { Total frequency } \\
\text { of genotypes, } \\
p \leq 5 \%\end{array}$ \\
\hline$A A / C C / A A / A A / C C$ & 0.133 & \multirow{8}{*}{29} & \multirow{8}{*}{23} & \multirow{8}{*}{0.450} \\
\hline$A A / C C / A G / A A / C C$ & 0.117 & & & \\
\hline$A G / C C / A A / A A / C C$ & 0.100 & & & \\
\hline$A A / C C / A A / A A / C T$ & 0.083 & & & \\
\hline$A A / C G / A G / A A / C C$ & 0.067 & & & \\
\hline$A G / C C / A G / A A / C C$ & - & & & \\
\hline$A G / C G / A A / A A / C C$ & 0.050 & & & \\
\hline$A G / C G / A G / A A / C C$ & - & & & \\
\hline \multirow[b]{2}{*}{$\begin{array}{l}\text { Predominate complex genotypes: } \\
R O R C / b G H / b G H R / L E P / L E P R\end{array}$} & \multicolumn{4}{|c|}{ Aberdeen Angus } \\
\hline & $\begin{array}{l}\text { Frequency of } \\
\text { predominate } \\
\text { genotypes }(p)\end{array}$ & $\begin{array}{l}\text { Number of } \\
\text { identified } \\
\text { genotypes }\end{array}$ & $\begin{array}{c}\text { Number of } \\
\text { genotypes, } \\
p \leq 5 \%\end{array}$ & $\begin{array}{c}\text { Total frequency } \\
\text { of genotypes, } \\
p \leq 5 \%\end{array}$ \\
\hline$A A / C C / A A / A A / C C$ & 0.152 & 0.152 & 0.152 & 0.152 \\
\hline$A A / C C / A G / A A / C C$ & 0.119 & 0.119 & 0.119 & 0.119 \\
\hline$A G / C C / A A / A A / C C$ & 0.203 & 0.203 & 0.203 & 0.203 \\
\hline$A A / C C / A A / A A / C T$ & - & - & - & - \\
\hline$A A / C G / A G / A A / C C$ & - & - & - & - \\
\hline$A G / C C / A G / A A / C C$ & 0.051 & 0.051 & 0.051 & 0.051 \\
\hline$A G / C G / A A / A A / C C$ & - & - & - & - \\
\hline$A G / C G / A G / A A / C C$ & 0.051 & - & - & - \\
\hline
\end{tabular}

Notes are the same as in Table 2

Table 5

Comparison of Russian Hornless and Aberdeen Angus cattle breeds according to the frequencies of economically important genotypes of the RORC, $b G H, b G H R, L E P$ and $L E P R$ genes

\begin{tabular}{|c|c|c|l|}
\hline Gene/genotype & Russian hornless & Aberdeen Angus & \multicolumn{1}{|c|}{ Economic value } \\
\hline RORC/AA & 0.616 & 0.474 & $\begin{array}{l}\text { Reduced fat content and marbling of } \\
\text { meat; getting leaner meat }\end{array}$ \\
\hline$b G H / C C$ & 0.683 & 0.661 & $\begin{array}{l}\text { Greater weight gain, reduced } \\
\text { marbling of meat; high milk yields, } \\
\text { high protein and fat content of milk }\end{array}$ \\
\hline$b G H R / A A$ & 0.566 & 0.610 & $\begin{array}{l}\text { Increase of milk fat; decline of meat } \\
\text { quality }\end{array}$ \\
\hline$L E P / A A$ & 0.867 & 0.797 & $\begin{array}{l}\text { Accumulation of energy, increase of } \\
\text { the productive longevity; increase of } \\
\text { fat in body, getting more fatty meat }\end{array}$ \\
\hline$L E P R / C C$ & 0.75 & 0.983 & $\begin{array}{l}\text { Increase of the fat content of milk, } \\
\text { best indicators of milk production }\end{array}$ \\
\hline$L E P R / C T$ & 0.25 & 0.017 &
\end{tabular}

In most cases, the frequencies of the economically valuable genotypes were slightly higher in the samples of the Russian Hornless breed than the frequencies of the corresponding genotypes in the Aberdeen-Angus subset (except the $A A$ genotype of the $b G H R$ gene), although these differences were not significant. In the Russian Hornless population we observed accumulation of the heterozygous genotype (25\%); its carriers among the Slovak Spotted cows were noted for the best indices of the milk producing ability [11]. In the samples of Aberdeen-Angus breed, the heterozygous genotype of 
the $L E P R$ gene was found only in one animal. The differences in the frequencies of homozygous $L E P R C / C$ genotype were significant $\left(t_{d}=3.981, p<0.001\right)$ in two breeds. The findings suggest that the Russian Hornless breed is not inferior to its parent form - the Aberdeen-Angus breed - in terms of representation of conducive to economic activity genotypes of the RORC, $b G H, b G H R$, and $L E P$ genes $[1 ; 10 ; 12]$, and is superior to it with respect to the frequency of the $L E P R C / T$ genotype associated with high milk producing ability. The $G G$ genotype of the $R O R C$ gene associated with the marbling of meat showed high frequency $(27.7 \%)$ in the Kalmyk breed, whereas its frequency in Russian Hornless and Aberdeen Angus breeds does not exceed $7 \%$. The $C C$ genotype of the $b G H$ gene associated with high meat and milk production is almost absent in the Kalmyk breed $(1.7 \%)$, while in the other two breeds this genotype was predominant [10].

These data suggest that the Russian Hornless breed developed on the basis of reproductive crossing of Kalmyk and Aberdeen Angus breeds, for the loci responsible for the trait potential, has more common traits with the Aberdeen Angus breed than with the Kalmyk one.

\section{Conclusions}

The high resource potential of the new Russian Hornless cattle breed was confirmed at the molecular genetic level. It should be noted that the breed developed can be used as a beef breed, and the dairy breed as well, as evidenced by the high content of genotypes preferred for obtaining high meat and milk performance.

\section{References}

1. Campos G.S., Braccini Neto J., Oaigen R.P. etc. Bioeconomic model and selection indices in Aberdeen Angus cattle. Journal of Animal Breeding and Genetics, 2014, vol. 131, pp. 305-312.

2. Gagaoua M., Claudia Terlouw E.M., Boudjellal A. etc. Coherent correlation networks among protein biomarkers of beef tenderness: What they reveal. Journal of Proteomics, 2015, vol. 128, pp. 365-374.

3. Huuskonen A., Pesonen M. Performance and meat quality of Nordic Red and Aberdeen Angus bulls offered faba bean or field pea based whole crop legumecereal silages. Agricultural and Food Science, 2016, vol. 25, pp. 1-12.

4. Gorlov I.F., Fedunin A.A., Sulimova G.E. etc. Polymorphisms of bGH, RORC, and DGAT1 genes in Russian beef cattle breeds. Russian Journal of Genetics, 2014, vol. 50, pp. 1302-1307.

5. Moiseikina L.G., Gendzhiev A.J., Chimidova N.V. etc. Immunogenetic markers of body type and body weight of calves of the Kalmyk breed. Biology and Medicine, 2014, vol. 6, art. no. BM-05514.

6. Левахин В.И., Макаев Ш.А., Габидулин В.М. и др. Волгоградский тип абердин-ангусского скота: монография (Volgograd type of Aberdeen Angus Cattle). Russia: Vestnik rossijskoj akademii sel'skohozjajstvennyh nauk, 2005. 150 p. (In Russian).

7. Амерханов Х.А., Белоусов А.М., Беляев А.И. и др. Русская комолая. Патент на селекционное достижение № 3779. Крупный рогатый скот (Russian Hornless. Patent for the selection achievement № 3779. Cattle. Bos primigenius Bojanus), 26.11.2007. (In Russian).

8. Амерханов Х., Горлов И., Каюмов Ф. и др. Новая порода мясного скота - русская комолая (New breed of beef cattle is Russian Hornless). Molochnoe i mjasnoe skotovodstvo, 2008, No 1, pp. 4-5. (In Russian).

9. Sulimova G.E., Voronkova V.N., Perchun A.V. etc. Characterization of the Russian beef cattle breed gene pools using Inter Simple Sequence Repeat DNA Analysis (ISSR Analysis). Russian Journal of Genetics, 2016, vol. 52, pp. 963-968.

10. Gill J.L., Bishop S.C., McCorquodale C. etc. Association of selected SNP with carcass and taste panel assessed meat quality traits in a commercial population of Aberdeen Angus-sired beef cattle. Genetics Selection Evolution, 2009, vol. 41, article \# 36.

11. Trakovicka A., Moravcikova N., Miluchova M. etc. Genetic polymorphisms of leptin and leptin receptor genes in relation with production and reproduction traits in cattle. Acta Biochimica Polonica, 2013, vol. 60, pp. 783-787.

12. Almeida S.E.M., Santos L.B.S., Passos D.T. etc. Genetic polymorphisms at the leptin receptor gene in three beef cattle breeds. Genetics and Molecular Biology, 2008, vol. 31, pp. 680-685. 